\title{
PENGARUH E-COMMERCE TERHADAP PENINGKATAN PENDAPATAN USAHA MIKRO KECIL DAN MENENGAH DI KOTA PADANG
}

\author{
Leni Gustina $^{1}$, Welia Novita ${ }^{2}$, Yohan Triadi ${ }^{3}$ \\ Universitas Putra Indonesia "YPYK" Padang Jl. Lubuk Begalung Padang \\ Email : lenigustina80@gmail.com ${ }^{1}$, wellianvt1@gmail.com ${ }^{2}$, yohan.ftr@gmail.com ${ }^{3}$
}

\begin{abstract}
The purpose of this study was to determine the effect of e-commerce on increasing revenue of BNIassisted MSMEs in Padang City. The object of the research is MSMEs in Padang City, West Sumatra. The formulation of the research problem is: how is the influence of e-commerce on increasing the income of Micro, Small and Medium Enterprises in Padang City. The research hypothesis is: ECommerce has a significant influence on increasing the income of MSMEs. The research approach is quantitative. The study population was 108 MSME units. The number of research samples was 52 MSMEs. Data collection using a questionnaire. Data analysis uses simple linear regression. The results of the study found: e-commerce has a significant effect on increasing revenue of MSMEs.
\end{abstract}

Keywords: E-commerce, Increased Income, MSMEs

\section{PENDAHULUAN}

Usaha mikro, kecil dan menengah (UMKM) merupakan salah satu praktik usaha populer di kalangan masyarakat. Banyaknya pegiat UMKM menjadikan sektor bisnis ini asebagai salah satu penggerak perekonomian negara. Selain itu UMKM juga mempunyai peran yang strategis dalam pembangunan ekonomi nasional, selain berperan dalam pertumbuhan ekonomi dan penyerapan tenaga kerja. UMKM mampu menjadi prioritas atau tulang punggung sistem ekonomi kerakyatan untuk mengurangi masalah kemiskinan dan pengangguran, selain itu UMKM juga berperan dalam pendistribusian hasilhasil pembangunan. Keberadaan UMKM merupakan satu hal yang sangat penting dalam perekonomian, dimana dalam kondisi ekonomi yang tidak kondusif,
UMKM adalah alternatif yang mampu mengurangi beban berat yang dihadapi perekonomian nasional.

Usaha kecil dan menengah atau UKM mempunyai peran penting terhadap pertumbuhan dan pembangunan perekonomian nasional. Hal ini dibuktikan saat ditengah terpaan krisis, sektor bisnis ini tetap berdiri meskipun banyak perusahaan besar mengalami stagnansi bahkan sampai berhenti. Ini karena meskipun pendapatan masyarakat menurun saat pandemi covid 19 namun tidak mempengaruhi permintaan barang dan jasa yang dihasilkan UMKM. Berbeda dengan kondisi usaha skala besar yang justru bertumbangan karena permintaan pasarnya kian berkurang. Sehingga Koperasi dan UKM dapat menyelamatkan perekonomian negara 
dan mampu mendorong pertumbuhan ekonomi. Berikut ini adalah kriteria usaha yang termasuk dalam Usaha Mikro Kecil dan Menengah yang telah diatur dalam payung hukum berdasarkan undang-undang.

Tabel 1. Penggolongan Kriteria UMKM Berdasarkan Asset Dan Omzet Pertahun

\begin{tabular}{|c|c|c|c|}
\hline \multirow{2}{*}{ No. } & \multirow{2}{*}{ Uraian } & \multicolumn{2}{|c|}{ Kriteria } \\
\hline & & Asset & Omzet \\
\hline 1 & Usaha Mikro & Maks. 50 Juta & Maks. 300 Juta \\
\hline \multirow{3}{*}{$\begin{array}{l}2 \\
3\end{array}$} & Usaha Kecil & $>50$ Juta -500 Juta & $>300-2,5$ Miliar \\
\hline & Usaha & 500 Juta -10 & $>2,5$ Miliar - 50 \\
\hline & Menengah & Miliar & Miliar \\
\hline
\end{tabular}
yang dapat menampung para pekerja Indonesia, Dalam kurun waktu lima tahun terakhir kontribusi sektor ini juga meningkat terhadap produk domestik bruto (PDB) dari 57,84\% menjadi 60,34\%. Dari tabel 1 di atas, penyerapan tenaga kerja sektor UMKM di Indonesia memang berperan sebagai lapangan pekerjaan. Hal ini terbukti dimana UMKM dapat menyerap sebanyak 97\% tenaga kerja Indonesia. Namun kondisi penyerapan tenaga kerja ini bersifat tidak stabil bahkan pada tahun 2015 mengalami penurunan yang cukup tinggi. Hal tersebut dikarenakan kurang berkembangnya UMKM yang disebabkan berbagai kendala baik yang bersifat internal maupun eksternal dalam sektor UMKM, sehingga perkembangan usaha menjadi terbatas.

Era globalisasi ekonomi yang disertai dengan perkembangan pesat teknologi, telah memberi kesan kepada persaingan yang sangat hebat di kalangan pengusaha-pengusaha dan seterusnya mengakibatkan perubahan ekonomi dunia yang sangat pesat. Kualitas produk adalah keseluruhan ciri dan karakteristik suatu barang atau jasa yang berpengaruh pada kemampuannya untuk memuaskan kebutuhan yang dinyatakan maupun tersirat (Abdullah \& Tantri, 2017:96). Selain itu, dalam penjualan produk juga harus menerima kenyataan akan

perkembangan teknologi yang cendrung akan berdampak pada margin keuntungan. Hal inilah yang menjadi kendala bagi UMKM di Indonesia saat ini. Kekurangan pengetahuan teknologi membuat UMKM di Indonesia ketinggalan dalam strategi pemasaran.

Dalam perkembangan tersebut, UMKM sebagai salah satu penopang perekonomian di Indonesia harus dapat menjawab tantangan tersebut dan harus mampu menjangkau perubahan disekitar. Komunikasi pemasaran haruslah dilakukan dengan sebaik dan seefektif mungkin kepada calon konsumen. Kegiatan periklanan berarti kegiatan menyebarluaskan berita (informasi) kepada pasar (masyarakat/ konsumen). Masyarakat perlu tahu siapa yang bertindak melalui media iklan tersebut (Mursid, 2017). Media Internet yang sekarang ini sedang ramai di perbincangkan menjadi daya tarik tersendiri dalam upaya menarik minat konsumen. Ditambah lagi dengan kebiasaan hidup di 
zaman sekarang ini yang menuntut serba praktis dan cepat membuat internet yang lebih dikenal dalam pemasaran sebagai sistem online makin digemari dan menjadi kebutuhan konsumen maupun produsen.

E-Bussines menggambarkan penggunaan alat dan kerangka dasar elektronik untuk melaksanakan bisnis perusahaan. E-commerce adalah perusahaan atau usaha menawarkan untuk transaksi atau memfasilitasi penjualan produk dan jasa secara e-commerce selanjutnya menimbulkan e-purchasing dan e-marketing. E-purchasing berarti perusahaan memutuskan membeli barang, jasa, dan informasi dari berbagai pemasok online. E-purchasing yang cerdas sudah menghemat jutaan dolar uang perusahaan. Emarketing menggambarkan usaha perusahaan untuk memberitahu pembeli, mengomunikasikan, mempromosikan, dan menjual produk dan jasa lewat internet (Kotler \& Keller, 2008:196). E-commerce belakangan ini digemari oleh kalangan produsen baik besar maupun kecil serta penjual eceran umumnya. Hal ini karena promosi melalui media online lebih mudah menjangkau konsumen dalam hal memperkenalkan atau menjual produknya. $E$ commerce mempermudah antara konsumen dan produsen dalam melakukan transaksi.

Seiring dengan ketatnya dalam persaingan berbisnis, Pengembangan pada sektor UMKM pun mulai menarik perhatian pemerintah supaya tidak tersisihkan dan terabaikan seiring dengan tantangan era ini dan rumitnya persaingan UMKM di Pasar global. Salah satu yang menjadi usaha pemerintah untuk pengembangan UMKM ini yaitunya dengan memberikan bantuan modal dan pelatihan kepada para pelaku UMKM. Selain itu karena sangat pentingnya peran UMKM dalam perekonomian bangsa, beberapa dari sekumpulan Badan Usaha Milik Negara seperti Bank BRI, BNI, Mandiri, BTN, Pertamina, Telkom dan PLN mendirikan Rumah Kreatif BUMN atau disingkat dengan RKB untuk mengembangkan kapabilitas dan kapasitas usaha-usaha dalam sektor tersebut.

Rumah Kreatif BUMN merupakan rumah bersama yang berperan sebagai pusat data dan informasi selain itu pusat edukasi, pengembangan, dan digitalisasi UMKM. Tujuan didirikannya RKB ini adalah sebagai upaya memperdayakan ekonomi kerakyatan, khususnya pelaku UMKM untuk meningkatkan kesejahteraan dan perekonomian Indonesia. Di Rumah Kreatif BUMN ini para pelaku UMKM dapat dibimbing dan didampingi untuk menjawab tantangan pengembangan usaha kecil menengah dalam hal peningkatan kompetensi, peningkatan akses pemasaran dan kemudahan akses permodalan.

PT. Bank Negara Indonesia Tbk (BNI) meresmikan Rumah Kreatif BUMN (RKB) 
BNI di Padang, Sumatera Barat. Realisasi RKB ini dilakukan BNI bersama sinergi BUMN. RKB BNI di Padang dapat digunakan bersama untuk mitra-mitra binaan dari berbagai BUMN. Salah seorang pegawai RKB BUMN menyatakan bahwa sebanyak 12.222 usaha mikro, kecil dan menengah (UMKM) dibina oleh rumah kreatif BUMN di Kota Padang, Sumatera Barat dan 108 di antaranya sudah aktif melakukan transaksi dalam jaringan (daring) atau online melalui situs jual beli blanja.com yang merupakan situs Online yang disediakan RKB BUMN untuk kegiatan jual beli bagi para pelaku UMKM.

Salah satu UMKM Binaan Rumah Kreatif BUMN tersebut yakni, usaha kain dan batik tanah liek yang bernama Ayesha. Sejak dibina, usaha tersebut terus berkembang dan pasarnya sudah internasional. Dalam satu bulan usaha ini sudah mencapai omset sebesar Rp. 50,000,000,00 per bulan. Sejak tergabung pada RKB BNI tersebut, UMKM ini sering ikut dalam pameran kerajinan baik di Sumatera Barat maupun tingkat nasional. Selain itu, contoh lainnya adalah Ida Nursanti, pemilik brand rendang Siti Nurbaya di Padang menjadi salah satu pelaku UKM di RKB BNI. Usahanya meliputi berbagai produk kuliner mulai dari aneka rendang, dendeng, ikan bilih, hingga aneka sambal siap saji. Omzet usahanya kini sudah mencapai Rp. 100,000,000,00 per bulan.
Sumatera Barat menjadi sasaran BNI untuk mendirikan RKB karena masyarakat Minang dikenal dengan produk kerajinan dan kulinernya, tetapi masih lemah untuk urusan marketing dan packaging produk. RKB memberikan pelatihan mengenai pola belanja online, membangun narasi produk, dan menjaga stok. Pembinaan dan pendampingan berupa pelatihan, sharing, konsultasi, dan quality control akan diberikan oleh RKB. Ada tiga hingga empat orang petugas yang akan mengarahkan para pengusaha UMKM untuk konsultasi, mentoring, dan coaching. Oleh karena itu, petugas RKB telah dibekali pengetahuan terkait pemahaman bisnis, pemanfaatan media sosial untuk bisnis, pemahaman bisnis online, teknik komunikasi, dan negosiasi.

RKB juga akan menyediakan pelatihan yang berjenjang, yaitu pelatihan dengan Modul Tingkat Dasar, Modul Tingkat Lanjutan, dan Modul Belajar Sendiri. Hal ini dilakukan untuk meningkatkan kapasitas dan kapabilitas pengusaha UMKM dalam menguasai e-commerce. Nantinya pelaku usaha dimungkinkan untuk melakukan konsultasi dan quality control serta registrasi UMKM dan analisa data. RKB juga menyediakan berbagai macam fasilitas seperti studio foto dan kamera untuk memotret produk disertai pelatihannya. Ada juga perangkat pendukung komputer untuk mengakses internet dalam memasarkan produknya. 


\section{TINJAUAN PUSTAKA}

\section{E-Commerce}

Usaha Elektronik Commerce (E-Commerce) atau lebih dikenal sebutan Online Shopping adalah pelaksanaan perniagaan berupa transaksi penjualan, pembelian, pemesanan, pembayaran, maupun promosi suatu produk barang dan/ atau jasa dilakukan dengan memanfaatkan komputer dan sarana komunikasi elektronik digital atau telekomunikasi data. Selain itu, bentuk perniagaan ini juga dapat dilakukan secara global, yaitu dengan menggunakan jaringan internet (Kuswiratmo, 2016:163).

Beberapa definisi telah diberikan untuk $e$ commerce (electronic commerce). Martin et al, mendifinisikan e-commerce sebagai penggunaan TI untuk melakukan kegiatan bisnis antara dua atau lebih organisasi, atau antara sebuah organisasi dengan satu atau lebih pelanggan akhir (endcustomer), melalui satu atau lebih jaringan komputer (Jogianto, 2005:286).

Elektronik commerce adalah transaksi komersial bidang jasa dalam format elektronik. (Transatlantic Business Dialogue Electronic Commerce White Paper). Elektronik commerce merujuk secara umum kepada semua bentuk transaksi yang berkaitan dengan aktivitas komersial, baik organisasi maupun individual, yang berdasarkan pada pemprosesan dan transmisi data yang digitalisasikan, termasuk teks, suara, dan gambar. (OECD) (Simarta, 2006:326). Definisi $e$ - commerce menurut Laudon, e-commerce adalah suatu proses membeli dan menjual produkproduk secara elektronik oleh konsumen dan dari perusahaan ke perusahaan dengan komputer sebagai perantara transaksi bisnis. Elektronik commerce berkaitan dengan melakukan dengan melakukan bisnis secara elektornik. E-commerce didasarkan pada pemprosesan elektronik dan transmisi data, termasuk teks, bunyi dan video. $E$ commerce mencakup segala macam aktivitas termasuk perdagangan elektronik baik barang atau jasa, pengiriman secara online dari isi digital, transfer dana secara elektronik, electronic share trading, electronic bil of landing, commercial auctions, kolaborasi desain dan rekayasa, online sourcing, public procurement, direct consumer marketing, dan layanan purnajual. Termasuk juga produk (consumer good, peralatan medis) atau jasa (layanan informasi, keuangan dan hukum); aktivitas tradisonal (kesehatan, pendidikan) dan aktivitas-aktivitas baru (virtual malls). (European Commission). Banyak orang mengira bahwa $e$ commerce dengan e-business adalah sama, namun pada kenyataannya berbeda. Pendapatan

Pendapatan merupakan nilai maksimum yang dapat dikonsumsi oleh seseorang dalam suatu periode dengan mengharap keadaan yang sama pada akhir periode seperti kedaan semula. Pengertian tersebut tidak menitik 
beratkan pada total kuantitatif pengeluaran terhadap konsumsi suatu periode. Pada hakekatnya pendapatan adalah penerimaan atau balas jasa dari faktor-faktor produksi. Penerimaan adalah penerimaan produsen dalam bentuk uang yang diperoleh dari hasil penjualan barang yang di produksi.

Menurut Keynes pendapatan yaitu perubahan pada jumlah faktor produksi yang digunakan dan perubahan kemampuan setiap unit faktor produksi tersebut menghasilkan pendapatan (Rosyidi, 2003:46). Pendapatan adalah hasil dari penjualan faktor-faktor produksi yang dimiliki kepada sektor produksi. Dalam makroekonomi, pendapatan adalah nilai barang dan jasa yang dihasilkan dalam satu tahun periode dalam suatu negara.

\section{Usaha Mikro Kecil dan Menengah}

Dalam undang-undang nomor 20 tahun 2008 tentang usaha mikro kecil dan menengah (UMKM) penyebutkan definisi UMKM adalah sebagai berikut:

a. Usaha Mikro adalah usaha produktif milik orang perorangan dan/atau badan usaha perorangan dengan jumlah kekayaan bersih atau hasil penjualan tahunan lebih besar dari usaha menengah sebagaimana diatur dalam UndangUndang ini.

b. Usaha Kecil adalah usaha ekonomi produktif yang berdiri sendiri, yang dilakukan oleh orang perorangan atau badan usaha yang bukan merupakan anak perusahaan atau bukan cabang perusahaan yang dimiliki, dikuasai, atau menjadi bagian baik langsung maupun tidak langsung dari Usaha Menengah atau Usaha Besar yang memenuhi kriteria Usaha Kecil sebagaimana dimaksud dalam UndangUndang ini.

c. Usaha Menengah adalah usaha ekonomi produktif yang berdiri sendiri, yang dilakukan oleh orang perorangan atau badan usaha yang bukan merupakan anak perusahaan atau cabang perusahaan yang dimiliki, dikuasai, atau menjadi bagian baik langsung maupun tidak langsung dengan Usaha Kecil atau Usaha Besar dengan jumlah kekayaan bersih atau penjualan tahunan sebagaimana diatur dalam UndangUndang ini.

\section{Kriteria Usaha Mikro Kecil dan Menengah}

Kriteria Usaha Mikro Kecil dan Menengah menurut UU Nomor 20 Tahun 2008 dalam pasal 6 bab IV adalah sebagai berikut:

a. Kriteria Usaha Mikro adalah sebagai berikut:

1) Memiliki kekayaan bersih paling banyak Rp. 50.000.000,00 (lima puluh juta rupiah) tidak termasuk tanah dan bangunan tempat usaha; atau

2) Memiliki hasil penjualan tahunan paling banyak Rp.300.000.000,00 (tiga ratus juta rupiah).

b. Kriteria Usaha Kecil adalah sebagai berikut: memiliki kekayaan bersih lebih dari Rp. 50.000.000,00 (lima puluh juta rupiah) 
sampai dengan Rp. 500.000.000,00 (lima ratus juta rupiah) tidak termasuk tanah dan bangunan tempat usaha; atau memiliki hasil penjualan tahunan lebih dari $\mathrm{Rp}$. 300.000.000,00 (tiga ratus juta rupiah) sampai dengan paling banyak Rp. 2.500.000.000,00 (dua milyar lima ratus juta rupiah).

c. Kriteria Usaha Menengah adalah sebagai berikut:

1) Memiliki kekayaan bersih lebih dari Rp. 500.000.000,00 (lima ratus juta rupiah) sampai dengan paling banyak Rp. 10.000.000.000,00 (sepuluh milyar rupiah) tidak termasuk tanah dan bangunan tempat usaha.

2) Memiliki hasil penjualan tahunan lebih dari Rp. 2.500.000.000,00 (dua milyar lima ratus juta rupiah) sampai dengan paling banyak Rp. 50.000.000.000,00 (lima puluh milyar rupiah).

\section{METODOLOGI PENELITIAN}

\section{Populasi}

Dalam penelitian ini subyek adalah UMKM di Rumah Kreatif BUMN BNI Kota Padang memiliki kriteria sebanyak 108 unit UMKM. Sampel adalah sebagian dari populasi yang terpilih dan mewakili populasi tersebut. Adapun teknik pengambilan sampel dalam penelitian ini adalah teknik sampel sampling purposive yaitu metode penetapan responden untuk dijadikan sampel berdasarkan pada kriteria-kriteria tertentu (Siregar, 2014). Dengan banyaknya jumlah populasi maka penulis membatasi dari jumlah populasi yang akan diteliti. Adapun kriteria pengambilan sampel yang penulis gunakan adalah: UMKM yang sudah terdaftar di RKB BNI Kota Padang, UMKM sudah melakukan transaksi jual beli di blanja.com. dan lama berdirinya UMKM (minimal 1 tahun). Populasi penelitian adalah sebanyak 52 UMKM.

\section{Teknik Pengumpulan Data}

Menggunakan kuesioner, yaitu suatu teknik pengumpulan data dan informasi yang memungkinkan untuk menganalisis mempelajari sikapsikap, keyakinan, perilaku, dan karakteristik beberapa orang utama di dalam organisasi yang bisa terpengaruh oleh sistem yang diajukan atau oleh sistem yang sudah ada. Teknik ini dilaksanakan dengan menggunakan daftar pertanyaan bentuk tertutup untuk memudahkan peneliti dalam menganalisis data. Survey dilakukan dengan membagikan kuesioner kepada responden pelaku usaha UMKM Kota Padang. Adapun skala yang digunakan adalah skala likert.

Sejumlah besar fakta dan data tersimpan dalam bahan yang berbentuk dokumentasi. Sebagian besar data yang tersedia yaitu berbentuk surat, catatan harian, cendera mata, laporan, artefak, dan foto. Untuk lebih mempertajam penelitian ini, maka penulis mendukung data yang penulis olah dengan menggunakan teknik wawancara. Teknik pengumpulan data dengan wawancara yaitu proses mencari dan mendapatkan informasi yang diperlukan dengan cara bertanya secara langsung kepada responden. 
Metode analisis data yang digunakan adalah dengan menggunakan pendekatan deskriptif kuantitatif dengan penelitian studi kasus yang dipergunakan untuk mengimpulkan, mengolah, dan kemudian menyajikan data obeservasi agar pihak lain dapat dengan mudah memahami objek dari penelitian tersebut. Setelah data terkumpul, selanjutnya data akan dianalisis dengan aplikasi yaitu SPSS. Namun, sebelum data tersebut dianalisis penulis perlu menguji apakah data tersebut valid dan realiabel. Adapun uji yang dilakukan adalah analisis regresi linier sederhana.

Dalam penelitian ini, analisis regresi linear sederhana berperan sebagai teknik statistik yang digunakan untuk menguji ada atau tidaknya pengaruh variabel $X$ terhadap variabel Y. Berikut adalah penjelasan variabel bebas dan variabel terikat yang akan diteliti pada

penelitian ini, yaitu: variabel bebas (X) adalah

Electronic commerce (E-commerce), dan variabel terikat (Y) adalah peningkatan pendapatan.

Uji signifikan parsial (Uji t), uji ini dilakukan untuk membuktikan pengaruh variabel bebas terhadap variabel terikat secara parsial (individu). Dengan kata lain, pengujian ini dilakukan untuk melihat keberartian dari masing-masing variabel secara terpisah (parsial) terhadap variabel tidak bebas. Pengujian dilakukan dengan membanding nilai $\mathrm{t}$ hitung dengan nilai $\mathrm{t}$ table dengan tingkat kesalahan $(\alpha)$ sebesar lima persen (5\%) dan derajad sebaran atau degree of freedom (df) sebesar n-k-1, dengan ketentuan pengambilan keputusan sebagai berikut:

a Jika $\mathrm{t}$ hitung $\geq$ dari $\mathrm{t}_{\text {tabel }}=\mathrm{H}_{0}$ ditolak dan $\mathrm{H}_{\mathrm{a}}$ diterima, berarti variabel bebas tersebut signifikan mempengaruhi variabel tidak bebas.

b. Jika $\mathrm{t}_{\text {hitung }} \leq$ dari $\mathrm{t}$ table $=\mathrm{H}_{0}$ diterima dan $\mathrm{H}_{\mathrm{a}}$ ditolak, berarti variabel bebas tersebut tidak signifikan mempengaruhi variabel tidak bebas (Nachrowi \& Usman, 2008:24- 25).

\section{HASIL DAN PEMBAHASAN}

\section{Regresi Linear Sederhana}

\section{Tabel 2. Hasil Uji Regresi Linear Sederhana}

\begin{tabular}{llrrrrr}
\hline \multirow{2}{*}{ Model } & \multicolumn{2}{c}{$\begin{array}{c}\text { Unstandardized } \\
\text { Coefficients }\end{array}$} & $\begin{array}{c}\text { Standardized } \\
\text { Coefficients }\end{array}$ & t & Sig. \\
\cline { 3 - 6 } & & \multicolumn{1}{c}{ B } & Std. Error & Beta & & \\
\hline \multirow{2}{*}{1} & (Constant) & 8.572 & 4.045 & & 2.119 & .039 \\
& e-commerce & .652 & .161 & .497 & 4.050 & .000 \\
\hline
\end{tabular}

Sumber : Data Primer Diolah (2018)

Hasil dari analisis regresi sederhana dapat dilihat pada tabel 2 diatas. Adapun hasil perhitungan tersebut adalah sebagai berikut:

a Konstanta sebesar 8.572 ini menunjukkan apabila variabel e-commerce mengalami peningkatan sebesar $1 \%$, maka variabel pendapatan juga akan mengalami peningkatan sebesar $8.572 \%$.

b. Koefisien regresi pada variabel independen yaitu e-commerce bertanda positif 0,652 , artinya menunjukkan setiap kenaikan $1 \%$ 
perkembangan e-commerce maka pendapatan mengalami peningkatan sebesar $0,652 \%$. Maksud dari hasil penelitian koefisien regresi bernilai positif berarti terjadi hubungan positif antara $e$-commerce dengan pendapatan.

\section{Uji t}

\section{Tabel 3. Hasil Uji t}

\begin{tabular}{cccc}
\hline & Model & t & Sig. \\
\hline \multirow{2}{*}{1} & (Constant) & 2.119 & 0.039 \\
& e-commerce & 4.05 & 0.000
\end{tabular}

Sumber : Data Primer Diolah (2018)

Berdasarkan hasil perhitungan dimana nilai signifikan e-commerce $0,000<$ dari $\alpha 0,05$ dan diketahui nilai $t_{\text {hitung }} 4,050>$ dari $\mathrm{t}$ tabel 2,009, maka e-commerce berpengaruh positif dan signifikan terhadap pendapatan UMKM binaan RKB BNI Padang. Jadi dapat disimpulkan bahwa Ha diterima Ho ditolak.

\section{KESIMPULAN}

Berdasarkan pembahasan dan analisis mengenai pengaruh e-commerce terhadap peningkatan pendapatan UMKM binaan RKB BNI Kota Padang, maka dapat ditarik kesimpulan bahwa variabel e-commerce $(\mathrm{X})$ berpengaruh signifikan terhadap variabel pendapatan (Y) UMKM binaan RKB BNI Kota Padang. Dengan dibuktikan nilai signifikan e-commerce secara parsial dari uji signifikan parametik individual (uji t) sebesar $0,000<$ dari $\alpha=0,05$. Sementara dari hasil analisis diketahui nilai thitung yaitu sebesar 4,050 > dari t tabel 2,009.

\section{DAFTAR PUSTAKA}

Abdullah, T. \& Tantri, F. (2014). Manajemen Pemasaran. Jakarta: Rajagrasindo.

Agustin, H. (2017). Studi Kelayakan Bisnis Syariah. Jakarta: Raja Grafindo.

Arikunto, S. (2005). Prosedur Penelitian Suatu Pendekatan Praktek. Jakarta: Raja Grafindo Persada.

Badroen, F., et al. (2015). Etika Bisnis dalam Islam. Jakarta: Prenadamedia.

Diredja, A.P. (1997). Perhitugan Pendapatan Nasional. Jakarta: LP3ES.

Humdiana, \& Evi, I. (2006). Sistem Informasi Manajeme. Yogyakarta: Graha Ilmu.

Husein, U. (2004) Metode Penelitian Untuk Skripsi dan Tesis Bisnis. Jakarta: Raja Grafindo. Idris. (2012). Aplikasi Model Data Kuantitatif dengan Program SPSS. Padang: UNP. Jogianto. (2005). Sistem Informasi Strategik untuk Keunggulan Kompetitif. Yogyakarta: Andi. Kuswiratmo, B.A. (2006). Memulai Usaha Itu Gampang!. Jakarta: Visimedia Pustaka.

Muana, N. (2001). Makro Ekonomi Teori, Masalah dan Kebijakan, Jakarta: Raja Grafindo.

Muhamad. (2013). Metodologi Penelitian Ekonomi Islam Pendekatan Kuantitatif. Jakarta: Rajawali.

Mursid. M. (2017). Manajemen Pemasaran. Jakarta: Bumi Aksara.

Nacrowi, D.N \& Usman, H. (2008). Penggunaan Teknik Ekonometrik. Jakarta: Raja Grafindo. 
Kotler, P., \& Keller, K.L. (2008). Manajemen Pemasaran. Jakarta: Erlangga.

Rosyidi, S. (2003). Pengantar Teori Ekonomi. Jakarta: Grafindo Persada.

Simarta, J. (2006). Pengenalan Teknologi Komputer dan Informasi. Yogyakarta: Andi Offset.

Siregar, S. (2014). Statistika Deskriptif untuk Penelitian: Dilengkapi Perhitungan Manual dan Aplikasi SPSS Versi 17. Jakarta: Rajawali Pers. Sadono, S. (1994). Pengantar Teori Ekonomi Mikro. Jakarta: Raja Grafindo.

Tarigan, R. (2015). Ekonomi Regional Teori dan Aplikasi. Jakarta: Bumi Aksara.

Yusuf, M. (2014). Metode Penelitian: Kuantitatif, Kualitatif, dan Penelitian Gabungan. Jakarta: Pranamedia. 